\title{
Vida religiosa consagrada feminina negra no Brasil
}

\author{
Orientador: Prof. Luís Corrêa Lima \\ Pesquisadora: Heloísa Helena Bento \\ Fonte: CCPG
}

\section{Introdução}

Em um primeiro momento foi realizada a leitura e pesquisa em alguns materiais bibliográficos que permitiram compreender toda a dinâmica da chegada de mulheres brancas ao novo Continente, bem como os motivos; a necessidade e a construção de casas de recolhimentos, sendo uma oficial e outra não. E a entrada da mulher negra nessas casas. Ora servindo na casa grande como escrava e raríssimas vezes, como fundadoras.

A partir daí iniciei as entrevistas. Em um primeiro momento, eu ia até a irmã e a entrevistava e em um segundo momento, por conta da Covid-19, enviei um questionário onde elas respondiam e depois me devolviam, mas achei que este formato ficou muito impessoal e com a ajuda da tecnologia passei a entrevista-las de forma online.

\section{Objetivos}

Este estudo tem como objeto a vida religiosa feminina negra na Igreja Católica no Brasil. Buscando como base para a sua construção elementos de como foi construída a sua identidade etno-racial, sua percepção histórica, social e política dentro da realidade em que vive. Busca-se também compreender a maneira como é vivida a sua missão e de que forma ela é usada ou não para conscientizar e ajudar aquele outro a tomar consciência de si, a construir a sua identidade, se reconhecer como pessoa e a partir daí ter confiança e segurança para traçar novos caminhos. 